\title{
PROTEIN-DNA ASSOCIATIONS IN A GENDER-SPECIFIC GENE OF SCHISTOSOMA MANSONI: CHARACTERIZATION BY UV CROSS-LINKING, DNase I FOOTPRINTING AND BAND SHIFT ASSAYS
}

\author{
SIMONE ENGELENDER \& FRANKLIN D. RUMJANEK
}

\begin{abstract}
Departamento de Bioquimica Médica, ICB/CCS, Universidade Federal do Rio de Janeiro, Cidade Universitária, Caixa Postal 68041, 21944-970 Rio de Janeiro, RJ, Brasil
\end{abstract}

\begin{abstract}
Protein extracts obtained from male and female schistosomes were incubated with a genderspecific gene, F-10, transcribed only in adult females and encoding a major egg-shell protein. The protein/DNA interaction was measured using the band shift, DNase-I-footprinting and UV cross-linking techniques. The results showed a clear band shift when a 302 bp restriction fragment containing the $3^{\prime}$ end of the gene was incubated with either female or male proteins. This fragment also contained a putative steroid hormone regulatory element (HRE). In contrast, only the male proteins produced a shift with the $495 \mathrm{bp}$ fragment corresponding to the middle region of the gene. DNase I footprinting showed that proteins from males and females interacted with the F-10 gene by binding to multiple adjacent sites along the DNA, thus generating relatively long protected fragments of approximately $100 \mathrm{bp}$. This result suggested that the adjacent binding of several moles of protein occurred at the $5^{\prime}$ end of the gene. UV cross-linking between schistosome proteins and a 21 bp synthetic oligonucleotide containing the F-10 HRE, evidenced proteins having MWS of 30,45 and $65 \mathrm{kDa}$. These proteins are presumably involved in the regulation of transcription of the F-10 gene.
\end{abstract}

Key words: Schistosoma mansoni - sexual maturation - gender - specific gene

Sexual maturation of females of Schistosoma mansoni depends a great deal on the presence of the male parasites (Shaw et al., 1977; Vandewaa et al., 1989; Rumjanek et al., 1989). Indirect evidence suggested the possibility that the events connected to the maturation process may be mediated by steroid hormones. The possible involvement of these hormones imply the occurrence of their cognate protein receptors, which classicaly, interact directly with the HRE of the target gene. The occurrence of a gender-specific gene, F10 , transcribed only by females and encoding a major egg-shell protein, has thus prompted the search for proteins which could regulate its transcription. The objectives of this paper were to establish whether gender-specific differences regarding protein/DNA interactions could be detected, to determine the protein binding sites in the gene itself and to identify the binding proteins.

This investigation received financial assistance from the UNDP/World Bank/WHO Special Programme for Research and Training in Tropical Diseases, CNPq, FINEP and The Rockfeller Foundation.

\section{MATERIALS AND METHODS}

Adult worms of $S$. mansoni were obtained by perfusion of Syriam hamsters (Smithers \& Terry, 1965). Protein extracts were obtained according to the method of Manley et al. (1980). The F-10 gene, cloned in the EcoR1 site of the PTZ $19 \mathrm{U}$ vector was purified by agarose gel electrophoresis followed by the Geneclean method 0 . DNA was 5 ' end-labelled with 32 p using polynucleotide kinese, according to the manufacturer's instructions. The band shift technique, UV activated protein/DNA cross-linking DNaseI footprinting were carried out according to methods published elsewhere (Rumjanek et al., 1989; Sorger \& Pelham, 1987; Galas \& Schmitz 1978).

\section{RESULTS AND DISCUSSION}

When the entire molecule of the F-10 gene $(908 \mathrm{bp})$ was cross-linked to schistosome protein extracts, the resolution did not permit unambiguous conclusions. The reason for this might reside on the fact that the use of a relatively long DNA molecule may have favored the binding of several 

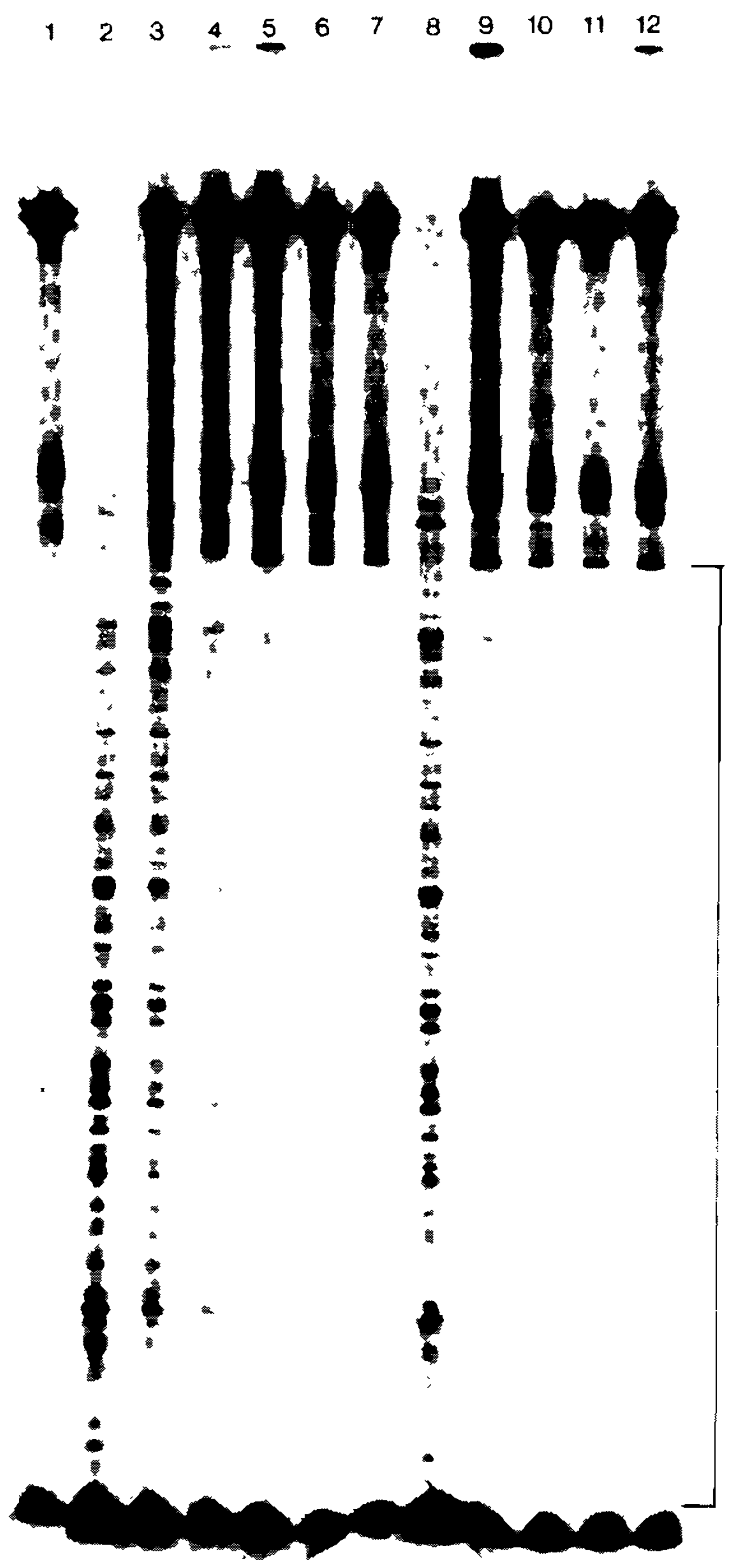

Fig. 1: DNase I footprinting of the binding of schistosome proteins with the F-10 gene ${ }^{32}$ P-F-10 was labelled according to methods yielding approximately $26000 \mathrm{cpm} / \mu$. This was incubated with: lane 1 , no proteins and no DNase I digestion. Lane 2, no protein and digestion with $5 \mu \mathrm{g} / \mathrm{ml}$ DNase l. Lane $3 \mathrm{idem}$ with digestion using I $\mu \mathrm{g} /$ 1 DNase I. Lanes 4 and $5,5.4 \mu \mathrm{g}$ of male schistosonte proteins digested with $5 \mu \mathrm{g} / \mathrm{ml}$ and I $\mu \mathrm{g} / \mathrm{ml} \mathrm{DNase} \mathrm{I}$ respectively. Lanes $6,7,10$ and 11 , same as before but with $10.8 \mu \mathrm{g}$ of male proteins. Lane $8,3.9 \mu \mathrm{g}$ of protein from female worms, digested with $5 \mu \mathrm{g} / \mathrm{ml}$ DNase 1 . Lane 9. samc but digested with $1 \mu \mathrm{g} / \mathrm{ml}$ DNase 1 . Lane 12, 16.2 $\mu g$ proteins from male schistosomes digested with $5 \mu \mathrm{g} / \mathrm{ml}$ I) Nase I.

moles of protein/mol DNA, as sugested in a previous publication (Rumjanck et al., 1989). This interpretation was confirmed by the results of the footprint analysis shown in Fig. 1. A clear footprint starting on the $5^{\prime}$ end and extending for about $100 \mathrm{bp}$, is observed when mixtures of male and female proteins arc added to the labelled DNA. Since generally the sites of contact between proteins and DNA span about $20-40 \mathrm{bp}$, the relatively large footprint observed in Fig. 1 suggested that proteins may be aligning themselves along the structure of the F-10 gene. Interestingly proteins from adult female worms failed to produce the same pat- 

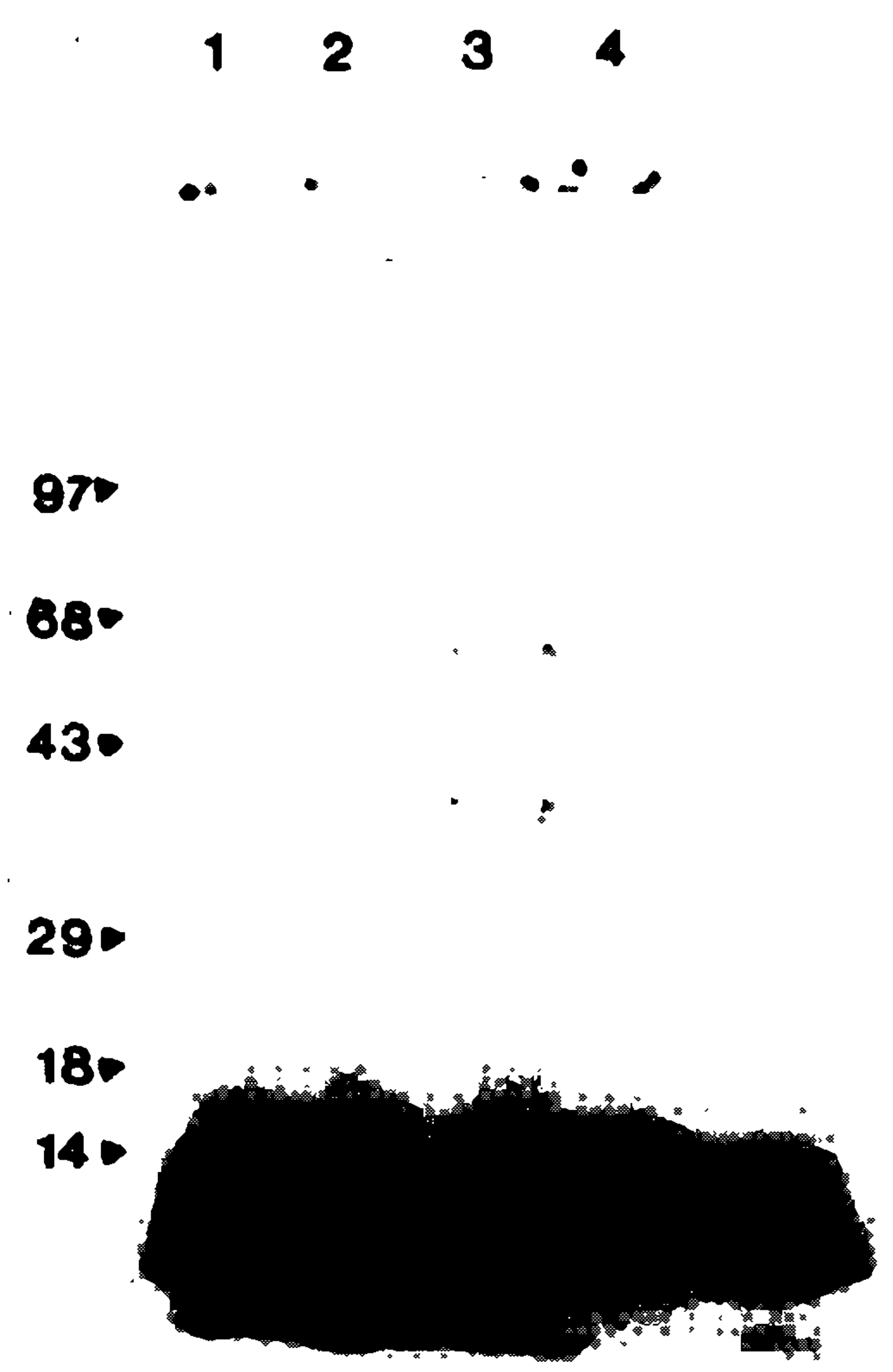

Fig. 2: UV cross-linking to the synthetic oligonucleotide. Total extracts of male and female schistosomes were incubated with 0.8 pnoles of ${ }^{32} \mathrm{p}$ labelled oligonucleotide (approx. $7.7 \times 10^{5} \mathrm{cpm} / \mathrm{reaction}$ ) as described in methods. Lane I. no proteins. Lanes 2 and 3,10 and $20 \mu \mathrm{g}$ respectively of male/female proteins. Lanes 4 and 5.10 and 20 Hg respectively of female proteins. UV irradiation was carried out for $10 \mathrm{~min}$.

tem, at the same DNase I concentrations used for male worms. At lower DNase I concentrations, however, female proteins produced a footprint of equal lenght, suggesting that these proteins bound to the DNA with lower affinity.

In order to restrict the protein binding to more specific domains, the protein extracts of schistosomes were cross-linked to a 21 bp synthetic double stranded oligonucleotide whose sequence was derived from the $3^{\prime}$ end of the F-10 gene. This sequence was: $5^{\prime}$ TCTCCACTGTCCTATTTTTCT 3'. The underlined region represents a consensus sequence typical of HRE's of genes regulated by steroid hormones. The results in fig. 2 show distinct bands obtained only with male schistosome protein extracts. The MW of the binding proteins ranged from approximately 32 to $65 \mathrm{kDa}$ (lanes 2 and 3 ). The 65 and $40 \mathrm{kDa}$ proteins were consistently observed in experiments testing the male/female protein extracts. On the other hand the female protein extracts produced only the $40 \mathrm{kDa}$ protein band. The fact that the number of bands increased proportionally to the male/female protein concentration is indicative of the formation of cooperative DNA/protein complexes.

Finally the band shift experiments in Fig. 3 show that the proteins from each sex bind differently to individual domains of the F-10 gene. For this experiment the F-10 DNA was treated with the enzyme Taq I, which generated three fragments of 107,302 and $495 \mathrm{bp}$. The $107 \mathrm{bp}$ and the $302 \mathrm{bp}$ fragments corresponded to the $5^{\prime}$ and $3^{\prime}$ ends of the gene respectively. The $107 \mathrm{bp}$ fragment displayed only a discrete shift with female proteins. Shifts were also produced by proteins from both sexes, though creating different patterns, when incubated with the 302 bp fragment. The middle region, consisting of a $495 \mathrm{bp}$ fragment bound strongly to the male proteins and less so to the female proteins. 


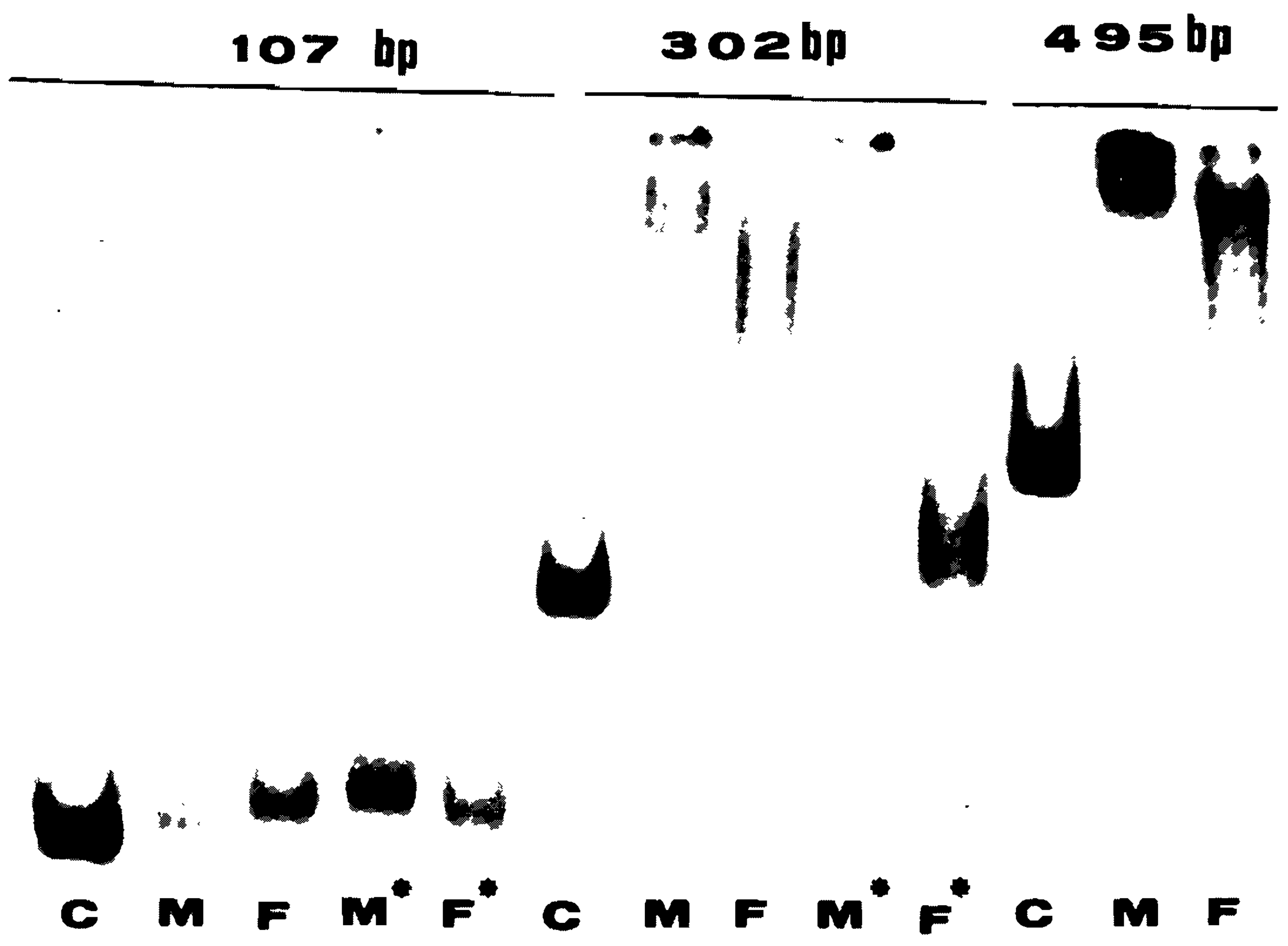

Fig. 3: band shift of restriction fragments of the F-10 gene. The F-10 gene was digested with the enzyme Taq I and the purified fragments $(107,302$ and $495 \mathrm{bp})$ were incubated with the protein extracts, followed by fractionation on $4 \%$ polyacrylamide gel electrophoresis. From left to right: no protein, $20 \mu \mathrm{g}$ male protein, $20 \mu \mathrm{g}$ of female protein, $20 \mu \mathrm{g}$ of male protein +40 pmoles of cold oligonucleotide, $20 \mu \mathrm{g}$ of female protein +40 pmoles of cold oligonucleotide, no protein, $20 \mu \mathrm{g}$ of male protein, $20 \mu \mathrm{g}$ of female protein, $20 \mu \mathrm{g}$ male protein +200 pmoles of cold oligonucleotide, $20 \mu \mathrm{g}$ of female protein +200 pmoles of cold oligonucleotide, no protein, $20 \mu \mathrm{g}$ of male protein and $20 \mu \mathrm{g}$ of female protein.

Whilst the interaction observed between male and female proteins with the two fragments corresponding to both ends of the gene may reflect the binding of several activators of replication and transcription, it is possible that proteins contained in the male extract which bind with high affinity to the $495 \mathrm{bp}$ fragment, may have a silencing function, i.e., permanently blocking the transcription of the F-10 gene in the male parasite.

\section{ACKNOWLEDGEMENTS}

To Sônia Cristina Freire and Maria Marta Rodrigues Freire for technical assistance.

\section{REFERENCES}

GALAS, D. J. \& SCHMITZ, A., 1978. DNase footprinting: a simple method for the detection of protein-DNA binding specificity. Nucl. Acids Res., 5: 3157-3170.

MANLEY, J. L.; FIRE, A.; CANO, A.; SHARP, P. A. \&
GEFTER, M. L., 1980. DNA dependent transcription of adenovinus genes in soluble whole-cell extract Proc. Natl. Acad. Sci USA, 77: 3855-3859.

RUMJANEK, F. D.; BRAGA, V. M. M. \& KELLY, C., 1989. DNA binding proteins of Schistosoma mansoni recognizing a hexanucleotide motif occurring in genes regulated by steroids. Comp. Biochem. Physiol., 94B: 807-812.

SHAW, J. R.; MARSHALL, I. \& ERASMUS, D. A., 1977. Schistosoma mansoni: in vitro stimulation of vitelline cell development by extracts of male worms. Exp. Parasilol. 42: 14-20.

SMITHERS, S. R. \& TERRY, R. J., 1965. The infection of laboratory hosts with cercariae of Schistosoma mansoni and the recovery of adult worms. Parasitology, 55: 695-700.

SORGER, P. K. \& PELHAM, H. R. B., 1987. Purification and characterization of a heat-shock element binding protein from yeast. EMBO, J., 6: 3035 3041 .

VANDEWAA, E. A.; MILLS, G.; CHEN, GUOZHONG; FOSTER, L. A. \& BENNETT, J. L., 1989. Physiological role of HMG-CoA reductase in regulating egg production by Schistosoma mansoni. Amer. J. Physiol., 26: R618-R625. 